\title{
JESUS AND HIS APOSTLES AS PROPHETS PAR EXCELLENCE IN LUKE-ACTS ${ }^{1}$
}

\author{
Sewon Moon \& Jeremy Punt \\ New Testament \\ Stellenbosch University
}

\begin{abstract}
In Luke-Acts, Jesus and his Apostles are characterized by language that is reminiscent of the Old Testament prophets, particularly Moses and Elijah. This article atttempts to understand the meaning of such characterization in the narrative world of Luke-Acts. This world includes the frameworks of Judaism of the first century as a hierocratic symbolic empire, the perception of the prophet par excellence like Moses in Judaism, and the plot and geographical movement of Luke-Acts. This article argues that the earthly Jesus (Lk. 4:16-30) and the Twelve Apostles after the Pentecost (Acts 2) are characterized in Luke-Acts as prophets par excellence who confront the current hierocratic symbolic empire, participating in the making and renewal of the Covenant, which underlies the identity of God's people.
\end{abstract}

Key Words: Luke-Acts; Characterization of Jesus; First Century Judaism; Prophet par excellence

\section{Introduction: Jesus and Apostles as Prophets in Luke-Acts}

Neither the Messiah nor his Apostles can be identified as having the general features of normal prophets of the first century Mediterranean world, ${ }^{2}$ yet Luke elaborates on them in such a way as to portray them as prophets (Johnson 1991:17-19). This raises two questions: How does Luke actually portray Jesus and the Apostles? Why does Luke portray Jesus and the Apostles as prophets?

\section{Tracing the Characterization of Jesus and his Apostles in Luke-Acts}

In this article, Luke-Acts is taken as the object of research. In spite of the fact that Luke's Gospel and Acts are not usually read together as one work in two volumes (Rowe 2007:451), the authorial, the narrative and the theological unity support the strong connection between two volumes (Parsons \& Pervo 1993:116-126). In addition to the prologues (Denova 1997:15), Jesus's departure/exaltation (Lk. 24; Acts 1) links the two volumes. In fact, this exaltation of Jesus makes the following story possible. Thus, Acts is best understood as a sequel to Luke (Rowe 2007:451), and Luke-Acts provides the best platform from which to investigate the author's literary and theological voice (Johnson 2005:162), including the matter of characterization of Jesus and his Apostles. It is true that

This article is based on an MTh thesis by Sewon Moon, which was submitted to Stellenbosch University in 2013, and supervised by J Punt.

2 Regarding various prophetic figures of the first century Mediterranean world, see Aune (1983). Generally, the prophetic figures in the Greco-Roman world were largely associated with the holy places and cults; and they gave prophecies in answer to consultations. 
characterization has been understood only as a literary matter, not as a matter of history. However, characterization was important in history as well.

Luke-Acts is classified as an ancient history in the present work. Prior to dealing with the matter of genre of Luke-Acts, ${ }^{3}$ the modern dichotomy between literature and history, and history and theology must be resolved. Before the $19^{\text {th }}$ century history existed as a branch of literature. Like rhetoricians, ancient historians were motivated by their own purpose, and used the techniques of persuasion, that is, rhetoric (Rothschild 2004:2). Yet this did not detract from their claim to authenticity (Keener 2009:108), because they used their rhetorical skills in a creative and discreet way for exposing truth $^{4}$ (Rothschild 2004:2). This applies equally to theology. In the ancient symbolic world in which divinity and humanity were linked, divine intervention functioned as an important literary technique for "describing events for which natural explanations fall short in terms of either plausibility for capturing an event's 'truth' or significance" (Rothschild 2004:9). Thus, theological purpose can be compatible with historical authenticity in ancient historiography. In this article, Luke-Acts is understood as an example of ancient history, and thus as a part of a branch of literature which, although written for a Christological purpose to persuade an audience to accept Jesus as Lord and Messiah, achieved this in indirect ways.

The author's purpose, to proclaim Jesus as Lord and Messiah (Bock 1987:277-278), is reflected in the narrative order of Luke-Acts. ${ }^{5}$ What is noticeable here is Luke's use of 'levelled hermeneutics', that is, the sequential comparison of Jesus to important figures to reveal the real identity of Jesus. He is firstly compared to important figures, before he is presented as excelling them in the next scene (Nobilio 2007:131).

In his description of the earthly Jesus, Luke portrays Jesus as a prophet, using various literary devices, Old Testament quotations and allusions, including typology, ${ }^{6}$ as well as the evaluative voices of Jesus' contemporaries in every crucial phase of Luke-Acts. In the process of the narrative, however, Jesus' real identity is heuristically identified - Jesus is Lord and Messiah. This process is summarized in Luke 24 as well as in Acts 2 (Croatto 2005:453-454). Luke's levelled hermeneutics leads readers/audiences from the conventional understanding of the historical Jesus as a prophet, to the confessional understanding of Jesus as Lord and Messiah. Jesus' status as a prophet is a point of departure in this levelled hermeneutics (Aune 1983:188).

Luke, one of the most Hellenized among the New Testament writers (Darr 1992:27), elaborately tries to persuade his audiences that 'the Way (Acts 9:2; 19:9,23)', which he and his companions handed over to them, originated in the OT. It is understandable, because referring to the OT was pivotal for the legitimation of a new teaching or a new group in a society in which tradition was of decisive importance (Alexander 1984:2). Luke understands and explains 'the events' concerning the life and death of Jesus, as well as the beginning and expansion of the Christian communities as corresponding to the pattern 'fulfilment of the prophecies' (Bock 1987:274-277; cf. Lk. 1:1; Acts 2:16). It is also the case with Luke's characterization of Jesus and his Apostles. Along with Hellenistic con-

Concerning the genre of Luke-Acts, see Bovon (2006), especially 509-511.

4 Rothschild (2004:1-2) indicates that by definition, history, a literary art of exposing truth, like philosophy, eschews rhetoric, contrary to arguing truth, the duty of politics, drama and law (Rothschild 2004:1-2).

5 It is especially the case when we consider the oral setting of the first century. [In their recitation] readers/audiences proceed to the information "in its intended order" (Darr 1992:43).

6 Quotations and allusions were perceived as having the same weight in the Judaism of the Second Temple era (Pao \& Schnabel 2008:251). 
http://scriptura.journals.ac.za

Jesus and his Apostles as Prophets par excellence in Luke-Acts

ventions, such as typical scenes and disputes over honour and shame, the OT quotations and allusions function as important literary devices in the characterization in Luke-Acts.

\section{The Value of 'a Pragmatic Reader Response Approach'}

"A pragmatic reader response approach: reading readers reading the text" proposed by John A Darr in his 'On Character Building' (1992), is a valuable approach for investigating the characterization of Jesus and his Apostles. ${ }^{7}$ Darr proposes a 'text-specific' reading, which understands that meaning emerges from the literary work which the readers [re]construct based on the given text, using the extra-textual repertoire. ${ }^{8}$ He recalls the importance of the rhetorical pattern ${ }^{9}$ and the narrative sequence of the text itself to understand the meaning of the text, as much as that of the cultural-historical context behind the text. Objecting to the extreme type of reader-response theory, Darr (1992:25) elaborately differentiates the ideal readers/audiences of the first century from modern critics. He clarifies that Luke-Acts is primarily written for the first century audience, who were literates of Hellenistic conventions and Jewish tradition - the OT in particular.

In this article the narrative world of Luke-Acts in both cultural-historical and literary contexts will first receive attention. Then two case passages, Luke 4:16-30 and Acts 2, will be investigated in terms of Hellenistic conventions and the inter-textual linkage, especially the Old Testament quotations and allusions, including typology. The focus remains throughout on the characterization of Jesus and his Apostles.

\section{Narrative World of Luke-Acts}

\section{Second Temple Judaism of the First Century: A Hierocratic Symbolic Empire}

Second Temple Judaism of the first century can be understood as a symbolic empire ${ }^{10}$ within the Roman Empire (Sterling 1999:202; cf. Parsons 2008:40). It was a hierocratic symbolic empire that was centred around the Temple of the metropolis, Jerusalem, and its high priests. This hierocratic feature was particular to the first century Judaism before 70 CE (Eliott 1991:220-223). In this period various competing Jewish groups existed as parts of the symbolic empire within it (Goodman 2011:26). In addition to the patronage of the Roman empire and the Herodian dynasty, the authority of a high priest was guaranteed by

7 In his "[pragmatic] reader response model attuned to the Greco-Roman literary culture of the first century", Darr (1992:14) is fully aware of the oral setting of the first century. For Darr (1992:28), 'the reader' as the ideal recipient of Luke-Acts indicates 'the literate reciter' rather than 'the illiterate audience'. In the course of recitation, however, the audience could participate in the dialogue called 'reading'. Luke 4:16-30 and Acts 2 give the examples of such 'reading' as the interactive dialogue among the writer (Isaiah and Joel) and the reciter (Jesus and Peter); the reciter and the audience (the entire house of Israel).

8 Darr (1992:25) lists the items of the extra-text repertoire as follows: (1) Language, (2) Social norms and cultural scripts, (3) Classical or canonical literature, (4) Literary conventions (genre, type scenes, standard plots, stock characters) and reading rules (how to categorize, rank, and process various kinds of textual data), (5) Commonly-known historical and geographical facts.

9 Through his literary research, Darr (1992: 53-58) concludes that the rhetorical pattern of Luke-Acts can be summarized as 'to see/hear and to respond/believe'. Rothschild reaches a similar conclusion through her historical research.

10 In his Against Flaccus 44-46, analogous to the Roman Empire, Philo identified Jerusalem with metropolis, and diaspora Jewish communities with colonies. Through this presentation, Philo tried to preserve diaspora Jews' Jewish identity (Sterling 1999:199). A similar understanding can be found in the materials of the Second Temple Judaism era (Jubilee 8:12; cf. 1En. 26:1; Pss. Sol. 11:1-7; Isa. 66:17-20; Ezek. 28:10-12) (as referred by Parsons 2008:40). 
the cult of the Jerusalem temple and the OT, which regulated it (Goodman 2011:35). When the Davidic political authority was removed, ${ }^{11}$ the high priests became the rulers of the symbolic empire who exercised some political power derived from their religious authority (Rooke 2000:3).

\section{Prophecy as a Prerequisite of the Leaders of the Sacred Nation Israel}

Ideologically, the experience of divine possession, including prophecy, was a prerequisite for all of Israel's leaders, including monarchs, priests, prophets and deliverers. Prophecy as a phenomenon was not the exclusive domain of the professional prophets. Prophecy can be understood as 'mediating the Divine', or more precisely, "transmission of allegedly divine messages by a human intermediary to a third party" (Jassen 2007:4). The clear-cut distinction of the three offices of ancient Israel, king, priest, and prophet does not seem to be so rigid. In fact, their roles overlap each other, even in the OT itself. For example, the first kings of Israel were initially called as prophets (1 Sam. 10, 16; cf. $1 \mathrm{Kgs} .3$, 9), and prophecy using the Urim and Thummim was one of the original tasks of the [high] priest (Ex. 28:30; Feldman 2007:238). Thus, what differentiated a prophet fundamentally from a king or a high priest was his or her origin, rather than prophetic phenomenon. Where a king was expected to have Davidic ancestry and a high priest from Zadok's, a prophet was not expected to have any specific ancestry. Simply put, prophets did not claim their 'ascribed' honourable status. Rather they claimed their authority as divine mediators based solely upon their prophetic commission.

\section{The Prophet par excellence ${ }^{12}$ and the Covenantal Order}

OT Prophets can be divided into two categories in terms of their relationship with the current hierarchical order (cf. Jassen 2008:311-312). ${ }^{13}$ Most of Israel's prophets were 'ordinary' prophets within the hierarchical system built on the current covenantal relationship of Israel. They performed the functional role of the transmission of God's will, including prediction of the future, to the covenantal community (e.g. $1 \mathrm{Kgs}$. 13:11-32). They did not replace a high priest, and therefore they could not offer sacrifices on their own (cf. Num. 16).

However, some prophets had authority exceeding the current hierarchical order, which was led by a monarch and a high priest. A prophet par excellence, such as Moses, performed the priestly tasks, sacrifices and anointing (Lev. 8), and more significantly, the legislative tasks (Jassen 2008:308). Their extraordinary authority derived from their intimate relationship with God (Num. 12:6-8; Deut. 18:15-22; 34:10-12).

\footnotetext{
11 In the pre-exilic period, the leadership of God's people was given primarily to 'sacred' monarchs, and [high] priests who were subordinated to those monarchs who took charge of (1) counselling of monarchs, and (2) sacrificing at the central temple (Rooke 2000:120-121). In Second Temple Judaism, the restoration of Israel was expected to be done by the Davidic Messiah, the son of David (Rooke 2000:238-239; Aune 1983:122124). However, in the period Luke-Acts deals with, the high priest exercised his autocratic function, including considerable juridical authority.

12 The notion of prophet par excellence like Moses was widely recognized in Second Temple Judaism, by the Qumran community (Jassen 2008:308), and by Philo (Levison 2006:206) and Josephus (Feldman 2006:215). 
It is noteworthy that the prophets par excellence such as Moses, Samuel and Elijah ${ }^{14}$ worked as mediators of the covenant, appearing at the crucial moments of making and renewing of the Covenant. ${ }^{15}$ Whereas kings and priests functioned within the Covenantal order, the prophets par excellence participated in the making/renewal of the Covenant itself. As for Samuel and Elijah, they worked as the alternative faithful [high] priests ${ }^{16}$ in the time of Israel's corruption (1 Sam. 2:35-36; 1 Kgs. 19:10, 14), which was often symbolized by the corruption of its priests (1 Sam. $2: 11-17$ ). Such a typology of the prophet par excellence as the alternative high priest ${ }^{17}$ and the mediator of the Covenant became the background of the characterization of Jesus and his Apostles.

\section{The Plot, Geographical Movement and Characterization of Jesus}

Presuming that the characterization of Jesus is developed along the narrative sequence in Luke-Acts, his characterization can be illustrated in the following four stages:

1) the anticipative characterization of Jesus as Lord and Messiah (Lk. 1-3),

2) the characterization of Jesus in the public ministry as the prophet par excellence (Lk. 4-19:27),

3) the characterization of Jesus in Jerusalem (Lk. 19:28-23), and

4) the characterization of Jesus after his resurrection and exaltation as Lord and Messiah (Lk. 24-Acts). ${ }^{18}$

The importance of Jerusalem in Luke's narrative and in his characterization of Jesus is noteworthy. In fact, Jerusalem is the starting point and the final destination of Luke's Gospel. Thus, the ministry of Jesus and his Apostles should be understood in the light of their relationship with the Jerusalem Temple and its high priests.

\section{Jesus, the Prophet par excellence in Luke 4:16-30}

The Nazareth sermon of Luke 4 is a good example of how the earthly Jesus is characterized. In terms of Hellenistic conventions, Jesus' speech in the synagogue of Nazareth is a public speech ${ }^{19}$ confronting the entire house of Israel which is represented by the Nazarenes

14 Aune (1983: 83) rightly observes the distinctive characters of Samuel, Elijah and Elisha. He classifies them as 'Shamanistic prophets'. However, he does not develop his observation any further.

15 See the similarities between Moses' (1) Sinai Covenant (Ex. 19, 24) and (2) the renewal of the Covenant at Moab (Deut. 29-33); (3) Samuel's renewal of the Covenant at Mizpah (1 Sam. 7:2-12) and (4) Gilgal (1 Sam. 11:15-12:25); and (5) Elijah's renewal of the Covenant at Mount Carmel (1 Kgs. 18:20-46).

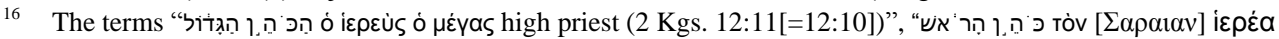
то̀v приิтоv chief priest (2 Kgs. 25:18)" were not used in the Pentateuch. In fact, the terms emerged in association with the cult of the central Temple in the period of Judah. However, Aaron (and Zadok) and their successors' superior status to other priests was widely recognized in Second Temple Judaism: Aaron was even called 'chief priest' (Ezra 7:5). The rather anachronistic term 'alternative high priest' is used here to emphasize the exclusive status of Aaron's successor.

17 The juridical roles of the high priest of the first century were (1) the interpretation of Torah, (2) law-giving on the basis of their interpretation, and (3) judgment according to the law (regulations).

18 In this illustration, I refer largely to Bock (1983). However, I do not fully agree with him, especially in section (2).Whereas he understands the earthly Jesus as the Davidic Messiah, I understand him as a prophet par excellence.

19 The first century synagogue was a public place where public affairs, including religious assemblies, were managed (Harding 2003:289). It is noteworthy that Torah was recited in the synagogue. This fact may imply 
who were a part of the hierocratic symbolic empire at that time. In addition, it can be understood as the dispute grounded in honour and shame over the status of Jesus as a prophet (Croatto 2005:455). It is highlighted by the audience's rhetorical question, "Is not this Joseph's son? (Lk. 4:24)" In terms of the narrative sequence of Luke-Acts, the conflict in Nazareth is the first occasion of the continuous subsequent conflicts between Jesus and the hierocratic symbolic empire. ${ }^{20}$ Rejection is presented as the mark of a true prophet (Denova 1997:132) along with "being sent by God" (Lk. 4:18, 26). Through the ironical emphasis on turning to the Gentiles in the Elijah/Elisha's paralleled typology (Lk. 4:25$27),{ }^{21}$ Jesus exposes the real state of Israel and calls for their repentance, warning about the result of disobedience. Here, Jesus accuses the whole house of Israel (Lk. 4:24), and confronts the current order, appealing to the typology of Elijah and Elisha (Lk. 4:25-27).

The inter-textual linkage of Luke 4:16-30 is revealed in the Isaiah quotation and the Elijah/Elisha typology. Following Poirier (2007:349-363), I presume that they are closely connected. Anointing (Luke 4:18) was usually associated with priests, not with prophets (Poirier 2007:353). The proclamation of the Jubilee year (Luke 4:19), which starts on the Day of Atonement, ${ }^{22}$ was also primarily a priestly task (Lev. 25:8-10). In addition, the ministries of Elijah and Elisha including offering sacrifices (Poirier 2007:354) and healing of leprosy (Lk. 4:27; cf. Lev. 13-14) can all be understood in terms of a priestly ministry. Yet, they were not from priestly ancestry, and were called as prophets (2 Kgs. 5:8). In fact, Elijah's priestly ministries should be understood in consideration of the ministries of his preceding prophets, Moses and Samuel. In many ways, especially in his sacrifice on Mount Carmel (1 Kgs. 18:21-40 and 1 Sam. 7:2-17) and anointing of kings (1 Kgs. 19:15-17 and 1 Sam. 10:1; 16:13), the portrayal of Elijah is reminiscent of that of Samuel. Samuel is portrayed further like Moses (Rooke 2000:58-59). Moses, Samuel and Elijah/Elisha were not priests, yet worked as priests. Thus, they can be identified as the prophets par excellence like Moses, who renewed the Covenant itself and worked as the alternative [high] priest, confronting the corrupted Israel.

In Jesus' declaration that he was the one who had been promised in Isa. 61, and in his identification of himself as a prophet such as Elijah and Elisha, Luke characterizes Jesus as a prophet par excellence like Moses. ${ }^{23}$ Jesus is thus introduced as a prophet par excellence who has proclaimed the new phase of the covenant and in so doing was confronting the current hierocratic symbolic empire in Lk. 4:16-30.

that Luke-Acts, with other NT writings, was recited in the worship of Jesus followers, rather than the setting of "sitting-round-the-fire-at-night-telling-tales" as Kebler and Dunn argue (Strelan 2008:65-66).

20 Stein (1992:152) assumes a response from the audience would have included the Jewish leadership in Jerusalem.

21 If we convert the divine passive voice of the Elijah/Elisha typology into the active voice, the theme will become clearer: God did not send prophets to Israel; God did not cleanse Israel.

However, this does not correspond to the whole picture of Elijah and Elisha. In fact, God sent prophets to Israel; and God wanted to cleanse Israel.

Thus, their ironical ministries can be best interpreted as the prophetic actions; and this episode cannot be used to prove the turning to the Gentile and the abandonment of Israel.

22 From the beginning, Jubilee theology was related to the 'forgiveness of sins', given that the Jubilee year is to begin with the sound of a trumpet signalling the Day of Atonement (Lev. 25:9). Thus, Luke's emphasis on 'forgiveness of sins' seems to be derived from OT itself.

23 Here I intentionally avoid the rather tricky term 'prophetic Messiah' to indicate a simple, yet often ignored, fact that generally prophets are not associated with 'anointing'. 
http://scriptura.journals.ac.za

Jesus and his Apostles as Prophets par excellence in Luke-Acts

Jesus, Lord and Messiah, and his Apostles as Prophets par excellence in Acts 2

To be sure, Luke's presentation of Jesus as a prophet par excellence is only a means that leads readers into a deeper understanding of Jesus (Aune 1983:188). Along the narrative sequence, Jesus is found to be superior to John the Baptist (Lk. 3:16-17), to the other prophets par excellence such as Moses and Elijah (Lk. 9), and to the regal Messiah like David (Lk. 20:41-44). Through his suffering, death, resurrection and exaltation, Jesus was proven to be the Lord and Messiah, the Lord of all (Lk. 24:26). Luke's hermeneutics embedded in his narrative sequence is ascribed to Jesus himself in his Gospel's last chapter (24:26, 46-47), "Was it not necessary that the Messiah should suffer these things and then enter into his glory?" This levelled hermeneutics is also found in the speeches of the Apostles, notably in Acts 2 (Parsons 2008:46). The final characterization of Jesus as Lord and Messiah in Acts 2 supports this ultimate purpose of Luke's hermeneutics. The purpose of Luke-Acts is to proclaim Jesus as Lord and Messiah (Bock 1987:277-278). Luke urges his readers to see and believe in Jesus as the Lord and Messiah given his historical authenticity.

It is also significant for the characterization of the Apostles in Acts 2. The Twelve Apostles have extraordinary authority in Luke-Acts (Luke 22:28-30; Acts 1:17, 21-26). Their characterization is, in fact, deeply connected to the characterization of exalted Jesus (Acts 2:33; cf. Denova 1997:29). ${ }^{24}$ As in Luke 4, Acts 2 can be explained as a public speech in front of the whole house of Israel in terms of the Hellenistic convention (Parsons 2008:41). Likewise, the dispute of honour and shame over the status of the Apostles is found from Acts 2. In terms of the narrative sequence, this is the first occasion of the Apostles' confrontation with the hierocratic symbolic empire (Fitzmyer 1998:232).

The inter-textual linkages concerning the characterization of the Apostles are found in the allusion to Moses and the Sinai covenant (Marshall 2007:531), and in the quotation of Joel (Acts 2:17-21). The phenomenon of the outpouring of the Spirit at Pentecost and the Joel prophecy are associated with Moses and the Sinai Covenant in terms of the day of salvation [and judgment]. The Law and the Spirit as the new Law, the birth of Covenantal Israel through the making of the Covenant (Joslyn-Siemiatkoski 2009:447-448) and the birth of a new nation through the making of the new Covenant sealed by the blood of Jesus are obviously parallels. The role of the Apostles in the making of the Covenant is also parallelled to that of Moses the prophet par excellence at Mount Sinai. The Apostles were 'anointed' with fire and the Spirit (2:1-4; Johnson 1992:42). Their 'intimate relationship with Lord Jesus ",25 and being eye-witnesses made them superior mediators compared to the high priests of the symbolic empire (2:33; cf. Johnson 1992:79-82). As prophets par excellence, they accused the people of Israel of $\sin (2: 23,36)$, mediated the renewal of the Covenant by calling for repentance and baptism (2:38-40), and performed signs and wonders" (2:43), confronting all of Israel. Through their mediation, the converts were born

24 Here Denova (1997:29) implies the independency of the Apostles' authority separately from Jesus. However, the Apostles' authority is thoroughly dependent on and subordinate to that of Jesus. It is "in the name of Jesus" that they proclaimed the forgiveness of sins (Acts 2:38) and healed a cripple (Acts 3:6).

25 It is noteworthy that the exalted Jesus, the co-regent of God (Acts 2:33), seems to replace the role of God in Acts. 


$$
\text { http://scriptura.journals.ac.za }
$$

Jesus and his Apostles as Prophets par excellence in Luke-Acts 8

again as the people of God. The converts experienced "the eschatological Jubilee order", 26 being taught by the Apostles, the prophets par excellence (2:43-47).

\section{Conclusion}

How does Luke characterize Jesus and his Apostles, and why does he do it? In the earthly ministry section, Jesus is depicted as a prophet par excellence. Such a description illuminates the characteristic of his public ministry. Jesus proclaimed the new phase of God's reign, confronting the hierocratic symbolic empire which was centred around the Temple and its high priests in Jerusalem. However, along with the narrative sequence, through Luke's levelled hermeneutics, Jesus is revealed to be superior to the other prophets par excellence. Exceeding the prophet par excellence who calls for the renewal of the Covenant and the restoration of Israel, Jesus is Lord and Messiah who concluded the new covenant with his blood, and who made the new covenant effective. Jesus was proven to be Lord and Messiah through his death, resurrection and exaltation. The Apostles, the prophets par excellence of Jesus, appear in the course of the making/renewal of God's people after the exaltation of Jesus. However, the exalted Jesus was with them and guided them to the end. Presuming that all these things were authentic historical facts that actually happened (Luke 1:1; cf. Rothschild 2004:21), Luke urges his readers to believe in Jesus as Lord and Messiah.

\section{BIBLIOGRAPHY}

Alexander, PS 1984. Textual Sources for the Study of Judaism. Manchester, UK: Manchester University Press.

Aune, DE 1983. Prophecy in Early Christianity and the Ancient Mediterranean World. Grand Rapids, MI: Eerdmans.

Bock, DL 1987. Proclamation from Prophecy and Pattern. JSNTS. 12. Sheffield, England: Sheffield Academic Press.

Bovon, F 2006. Luke the Theologian: fifty-five years of research (1950-2005). Waco, TX: Baylor University Press.

Croatto, JS 2005. Jesus, Prophet like Elijah and Prophet-Teacher like Moses in Luke-Acts JBL 124(3):451-465.

Darr, JA 1992. On Character Building: The Reader and the Rhetoric of Characterization in Luke-Acts. Louisville, KY: Westminster/John Knox Press.

Denova, RI 1997. The Things Accomplished Among Us: Prophetic Tradition in the Structural Pattern of Luke-Acts. Studies in Scripture in Early Judaism and Christianity. 4. Sheffield, England: Sheffield Academic Press.

Elliott, JH 1991. Temple versus Household in Luke-Acts: A Contrast in Social Institutions, in Neyrey, JH (ed.), The Social World of Luke-Acts, 211-240. Peabody, MA: Hendrickson.

26 It is characterized by (1) the forgiveness of sins/acquittal of debts which is expressed in the converts' distribution of their possession (Acts 2:44-45), and (2) the fact that the Holy Spirit poured out to all including the marginalized people who were asked to be silent (Acts 2:17-18) and the Gentiles (Acts 2:39). 
http://scriptura.journals.ac.za

Jesus and his Apostles as Prophets par excellence in Luke-Acts

Feldman, LH 2006. Prophets and Prophecy in Josephus, in Floyd, MH \& Haak, RD (eds.), Prophets, Prophecy and Prophetic Texts in Second Temple Judaism, 210-239. New York/London: T\&T Clark.

Fitzmyer, JSJA 1998. Acts of the Apostles. Anchor Bible. New York: Doubleday.

Goodman, M 2011. Religious Variety and the Temple in the Late Second Temple Period and Its Aftermath, in Stern, S (ed.), Sects and Sectarianism in Jewish History, 21-37. Leiden/Boston: Brill.

Harding, M 2003. Early Christian Life and Thought in Social Context: A Reader. London/New York: T\&T Clark.

Jassen, AP 2007. Mediating the Divine: Prophecy and Revelation in the Dead Sea Scrolls and Second Temple Judaism. Studies on the Texts of the Desert of Judah. 68. Leiden: Brill.

Jassen, AP 2008. The Presentation of the Ancient Prophets as Lawgivers at Qumran. JBL 127:307-337.

Johnson, LT 1991. The Gospel of Luke. Sacra Pagina. 3. Collegeville, KY: The Liturgical Press.

Johnson, LT 2005. Literary Criticism of Luke-Acts: Is Reception History Pertinent? JSNT 28/2:159-162.

Joslyn-Siemiatkoski, D 2009. Moses Received the Torah at Sinai and Handed it on (Mishnah Avot 1:1): The Relevance of the Written and Oral Torah for Christians. Anglican Theological Review 91.3:443-466.

Keener, CS 2009. The Historical Jesus of the Gospels. Grand Rapids, MI: Eerdmans.

Levison, JR 2006. Philo's Personal Experience and the Persistence of Prophecy, in Floyd, MH \& Haak, RD (eds.), Prophets, Prophecy, and Prophetic Texts in Second Temple Judaism, 194-209. New York/London: T\&T Clark.

Marshall, IH 2007. Acts, in Beale, GK \& Carson, DA (eds.), Commentary on the New Testament Use of the Old Testament. Grand Rapids, MI: Apollos.

Nobilio, F 2007. The implied definition of the prophet and its middle platonic trajectory in the Gospel of John. Neotestamentica 41/1:131-156.

Pao, DW \&Schnabel, EJ 2007. Luke, in Beale, GK \&Carson, DA (eds.), Commentary on the New Testament Use of the Old Testament, 251. Grand Rapids, MI: Apollos.

Parsons, MC 2008. Acts. Grand Rapids, MI: Baker Academic.

Parsons, MC \& Pervo, RI 1993. Rethinking the Unity of Luke and Acts. Minneapolis, $\mathrm{MN}$ : Augsburg Fortress.

Poirier, JC 2007. Jesus as an Elijanic Figure in Luke 4:16-30. CAQ 69:349-363.

Rooke, DW 2000. Zadok's Heir: The Role and Development of the High Priesthood in Ancient Israel. Oxford, UK: Oxford University Press.

Rothschild, CK 2004. Luke-Acts and the Rhetoric of History: An Investigation of Early Christian Historiography. WUNT 2. Reihe. 175. Tübingen: Mohr Siebeck.

Rowe, CK 2007. Literary Unity and Reception History: Reading Luke-Acts as Luke and Acts. JNST 29/4:449-457.

Stein, RH 1992. Luke. NAC. Nashville, TN: Broadman Press. 
http://scriptura.journals.ac.za

Jesus and his Apostles as Prophets par excellence in Luke-Acts

Sterling, GE 1999. "Opening the Scriptures": The Legitimation of the Jewish Diaspora and the Early Christian Mission, in Moessner, DP (ed.), Jesus and the Heritage of Israel, 199-217. Harrisburg, PA: Trinity Press International. 